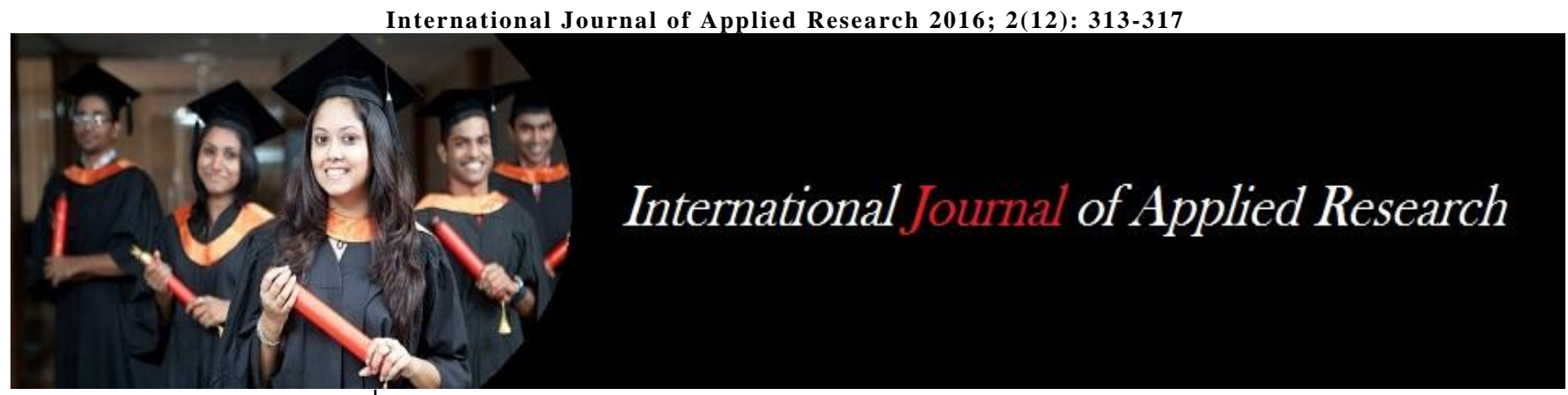

ISSN Print: 2394-7500 ISSN Online: 2394-5869 Impact Factor: 5.2 IJAR 2016; 2(12): 313-317 www.allresearchjournal.com Received: 15-10-2016 Accepted: 16-11-2016

Ishita Sarkar

PG Student, Department of Zoology, CBPB University, Coochbehar-736101, WB, India

Debattam Bhattacharjee PG Student, Department of Zoology, CBPB University, Coochbehar-736101, WB, India

Debashis Das

Department of Zoology,

Tufanganj Mahavidyalaya,

Coochbehar-736160, WB, India

Correspondence

Debashis Das

Department of Zoology,

Tufanganj Mahavidyalaya,

Coochbehar-736160, WB, India

\section{Zooplankton diversity recorded from the man-made wetlands of Cooch Behar town of West Bengal, India}

\author{
Ishita Sarkar, Debattam Bhattacharjee and Debashis Das
}

DOI: http://dx.doi.org/10.22271/allresearch.2016.v2.i12e.05

\section{Abstract}

The district Coochbehar lies between $26^{0} 17^{\prime} 58.57^{\prime \prime}$ to $26^{0} 20^{\prime} 23.722^{\prime \prime} \mathrm{N}$ and $89^{0} 26^{\prime} 01.74$ " to $89^{\circ} 27^{\prime} 34.26$ " E and is a part of Terai Himalaya of West Bengal of India. This district has a unique character of floral and faunal diversity for its geographical position which is adjacent to Indo-Malayan Hotspot. A number of lentic and lotic wetlands are present in this district as the district is located in a flood prone area. A large number of artificial wetlands are also present in the Coochbehar town most of which were created during the 'Koch dynasty' to cater the needs of the society. Some of them are Sagardighi, Rajmatadighi, Malidighi, Boiragidighi, Narasingha dighi, Lamba dighi, Laldighi etc. All these wetlands harbour a large number of Zooplanktons which are very important for their role as a part of second trophic level in aquatic ecosystem, that we had recorded during our study at UG level as a course curriculum of the syllabus. Our report is an extension of our previous study at UG and PG level based on the diversity and distribution of Zooplankton recorded from the man-made wetlands of Coochbehar town. This study recorded 14 Arthropods and 7 Rotifer from 7 man-made wetlands of the town. Detail diversity indices and Fisher (alpha) abundance index are analyzed. High counting of Cyplops from two wetlands indicating high level of organic pollution needs further limnological investigation.

Keywords: Zooplankton, diversity, wetland, Coochbehar town

\section{Introduction}

The district of Coochbehar is situated in the foothills of the Eastern Himalayas of West Bengal. It lies between $26^{0} 17^{\prime} 58.57^{\prime \prime}$ - 26020'23.72" North Latitude and 89 $26^{\prime} 01.74$ " $89^{0} 27^{\prime} 34.26^{\prime \prime}$ East Longitude. The town is located at the North-Eastern part of West Bengal; bounded by the district of Alipurduar in the north and Jalpaiguri in the west, state of Assam in the east and the International Border in the form of Indo-Bangladesh boundary in the south. Coochbehar town, popular for its historic palace of Maharaja which looks like Buckingham palace of England, is the district town and one of the planned town of West Bengal. A number of artificial wetlands (ponds) are present in Coochbehar town, most of which were created at the time of 'Koch dynasty'. Some of them are Sagar dighi, Rajmata dighi, Mali dighi, Bairagi dighi, Narasingha dighi, Lamba dighi, Lal dighi etc. Perhaps the nomenclature of these ponds was according to their size, shape or purpose of utilization. All these wetlands harbor a large number of Zooplanktons which are very important for their role as a part of second trophic level of aquatic ecosystem, that we had studied during our Under Graduate and Post Graduate courses as a curriculum of the syllabus.

Planktons are also indicator of water health (Datta, 2011; Harris and Vinobaba 2012; Pal et al. 2015a) ${ }^{[1-3]}$. Composition and community structure of Zooplanktons are sensitive to nutrient enrichment and level of pollution (Ahmed et al. 2011) ${ }^{[4]}$. Besides playing an integral role as bio-indicator, it also influences all the functional aspects of an aquatic ecosystem, such as food chains, food webs, energy flow and cycling of matter (Das et al. 2013) ${ }^{[5]}$.

A number of research publications are available regarding the diversity and distribution of planktons of wetlands of North Bengal, such as Datta $(2011)^{[1]}$ tabulated the zooplanktons of the wetlands of Jalpaiguri district, Mondal et al. (2012) ${ }^{[6]}$ on the Rotifer diversity of Mirik lake of Darjeeling Himalaya, again Mondal et al. (2013) ${ }^{[7]}$ on the Cladocera and Copepods 
of the same lake, Patra et al. (2015) ${ }^{[8]}$ on the Zooplankton diversity of the lake situated at Moraghat forest in Jalpaiguri district. Only a few papers are available about the zooplanktons of Coochbehar district, such as Das et al. (2012, 2013) ${ }^{[5,9]}$ published papers on the diversity and density of Zooplanktons from the Rasik beel wetland complex of Coochbehar district, Pal et al. (2015a) [3] compared the zooplankton availability in an artificial pond and a natural wetland of Coochbehar district, again in a study Pal et al. (2015b) ${ }^{[10]}$ recorded fifteen types of Zooplankton from the Panishala beel situated $8 \mathrm{~km}$ away from Coochbehar town.

But there is no publication available on the diversity of the zooplanktons of the wetlands of Coochbehar town. This report is an extension work of our previous study at Under Graduate course and $2^{\text {nd }}$ semester Post Graduate level based on the diversity and distribution of Zooplankton recorded from the man-made wetlands of Coochbehar town. In this study we have recorded the Zooplanktons of 7 man-made ponds of Coochbehar town namely, Sagar dighi, Lamba dighi, Bairagi dighi, Lal dighi, Narasingha dighi, Rajmata dighi, Dangarai dighi and from Policeline dighi. Spot locations of the studied ponds were presented in Plate 1.
Ponds were selected considering their different size, location and daily use by the local people.

\section{Materials and Methods}

Water samples were collected periodically from three randomly selected zones of each wetland during morning session $(6.30$ to $7.30 \mathrm{am})$. Zooplankton samples were isolated from the study sites by filtering 30 liters of subsurface water through a fine nylon mesh (50 No.) conical zooplankton net. The content collected in a plankton tube which was attached to the lower end of the net and the content was then transferred to separate tube instantly. The collected zooplankton organisms were preserved in $4 \%$ formalin solution. Identification was carried out using a compound microscope having 4X objective lens following

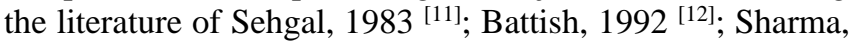

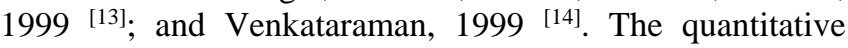
analysis of planktonic organisms was carried out using Sedgwick Rafter plankton counting cell. Three indices were used to obtain the estimation of species diversity (Shannon and Weaver 1949) ${ }^{[15]}$, species richness (Margalef, 1951; Menhinick, 1964) ${ }^{[16,17]}$ and species evenness (Pielou, 1966; Sheldon, 1969) ${ }^{[18,19]}$.

Table 1: Checklist of Zooplanktons recorded from different Pond of Coochbehar Town

\begin{tabular}{|c|c|c|c|c|c|c|c|c|}
\hline \multirow[b]{2}{*}{ Common / Scientific Name } & \multicolumn{8}{|c|}{ Status in different Ponds (in 30 lit.) } \\
\hline & $\begin{array}{c}\text { Bairagi } \\
\text { dighi }\end{array}$ & $\begin{array}{c}\text { Lamba } \\
\text { dighi }\end{array}$ & $\begin{array}{c}\text { Rajmata } \\
\text { dighi }\end{array}$ & $\begin{array}{c}\text { Lal } \\
\text { dighi }\end{array}$ & $\begin{array}{c}\text { Dagarai } \\
\text { dighi }\end{array}$ & $\begin{array}{c}\text { Narasingha } \\
\text { dighi }\end{array}$ & $\begin{array}{l}\text { Sagar } \\
\text { dighi }\end{array}$ & $\begin{array}{c}\text { Poloceline } \\
\text { dighi }\end{array}$ \\
\hline \multicolumn{9}{|c|}{ Phylum: Arthropoda : Sub-phylum: Crustacea } \\
\hline Nauplius larva & 00 & 00 & 390 & 90 & 90 & 00 & 420 & 210 \\
\hline \multicolumn{9}{|c|}{ Class: Branchiopoda : Order: Cladocera } \\
\hline Moina sp & 30 & 390 & 120 & 270 & 390 & 00 & 00 & 00 \\
\hline Alona $s p$ & 00 & 00 & 60 & 00 & 00 & 30 & 90 & 30 \\
\hline Daphnia sp & 00 & 00 & 00 & 90 & 30 & 00 & 30 & 00 \\
\hline Diaphanosoma sp & 210 & 180 & 1560 & 240 & 30 & 00 & 00 & 00 \\
\hline Chydorus sp & 120 & 00 & 00 & 00 & 00 & 90 & 00 & 60 \\
\hline \multicolumn{9}{|c|}{ Class: Maxillopoda : Sub-class: Copepoda } \\
\hline Cyclops sp & 1260 & 2760 & 930 & 1800 & 1410 & 1440 & 300 & 90 \\
\hline Mesocyclops sp & 120 & 300 & 160 & 1200 & 00 & 00 & 00 & 00 \\
\hline Tropocyclops $s p$ & 320 & 450 & 580 & 600 & 540 & 420 & 120 & 30 \\
\hline Diaptomus $s p$ & 30 & 00 & 00 & 00 & 60 & 00 & 60 & 00 \\
\hline Neodiaptomus $s p$ & 120 & 90 & 30 & 120 & 480 & 30 & 60 & 00 \\
\hline Heliodiaptomus $s p$ & 150 & 2160 & 460 & 1690 & 710 & 30 & 00 & 90 \\
\hline \multicolumn{9}{|l|}{ Class: Ostracoda } \\
\hline Cypris sp & 390 & 120 & 00 & 00 & 00 & 210 & 00 & 00 \\
\hline Hemicypris sp & 30 & 00 & 00 & 00 & 180 & 30 & 60 & 00 \\
\hline \multicolumn{9}{|l|}{ Phylum: Rotifera } \\
\hline Brachionus sp & 1980 & 1290 & 520 & 210 & 120 & 960 & 210 & 1320 \\
\hline Lacane $s p$ & 120 & 00 & 00 & 60 & 360 & 00 & 00 & 00 \\
\hline Epiphanes sp & 60 & 00 & 00 & 00 & 630 & 00 & 00 & 00 \\
\hline Conochilus sp & 00 & 00 & 30 & 00 & 00 & 60 & 00 & 00 \\
\hline Keratella $s p$ & 90 & 120 & 180 & 00 & 120 & 210 & 330 & 00 \\
\hline Ascomorpha sp & 00 & 00 & 30 & 00 & 30 & 30 & 210 & 00 \\
\hline Rotaria $s p$ & 00 & 00 & 00 & 00 & 00 & 00 & 60 & 00 \\
\hline
\end{tabular}

\section{Results and discussion}

Altogether 21 zooplankton species including one larval form were recorded during the course of our study. Checklists of the recorded zooplanktons are tabulated in Table 1. Out of these, 14 were recorded from the phylum Arthropod of which one is crustacean larva i.e. Nauplius, 5 belongs to cladocera, 6 copepods, 2 ostracoda and other 7 species recorded from the phylum Rotifer. Highest populations were recorded from Lamba dighi then Lal dighi. Policeline dighi and Sagar dighi showed very low record of total population counting. Stacked column diagram representation of the recorded zooplanktons from the different ponds of 
Coochbehar town are presented in Plate 2. Cyclops (belongs to copepods of Arthropods) and Brachionus (Rotifer) are the dominating species recorded from all ponds. The population of Heliodiaptomus (copepods) is next to them which are recorded from all ponds except Sagar dighi which is the biggest in size in Coochbehar town.

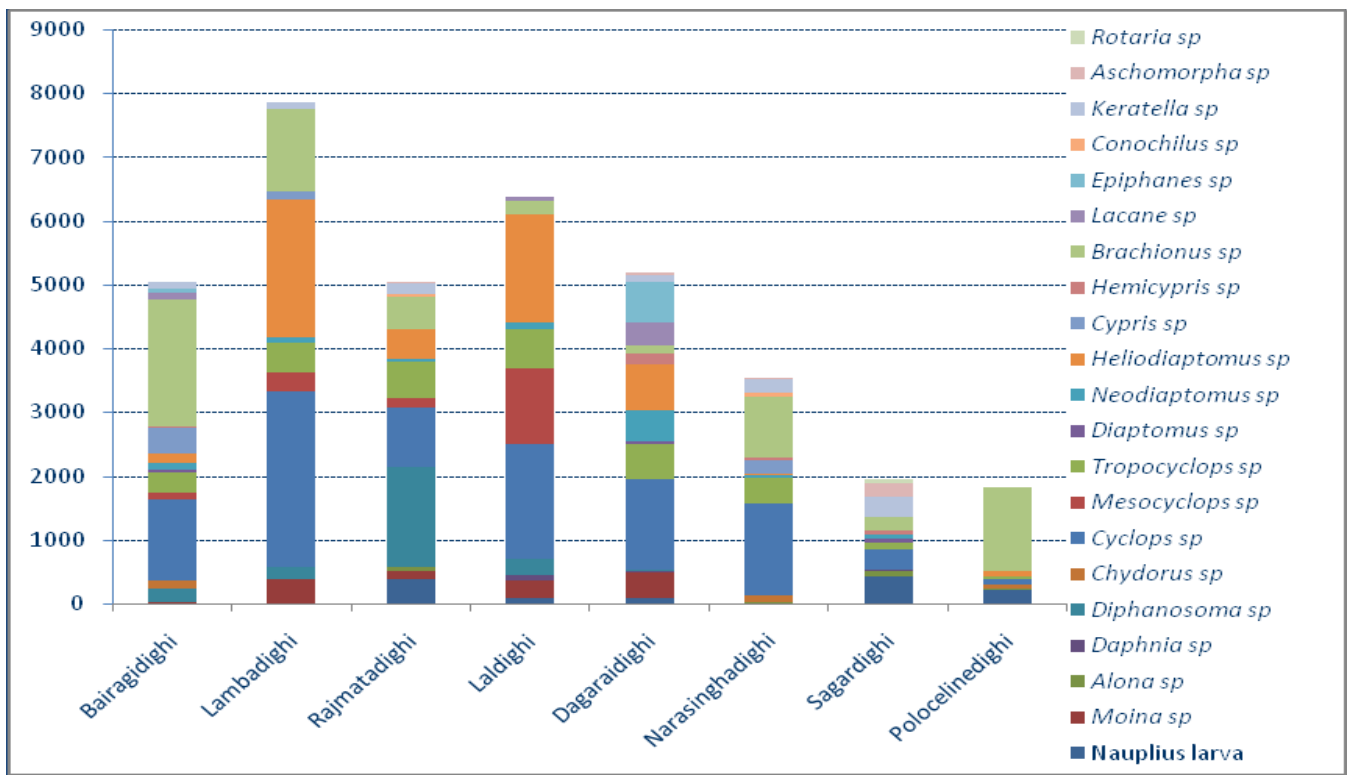

Plate 2: Stacked column diagram of recorded Zooplanktons from different Ponds of Coochbehar Town of West Bengal

Table 2 represents the diversity indices of the recorded zooplanktons using Past (PAleontological STatistics) software (version 3.14) [Hammer et al. (2001)]. Species richness is high in Dangrai dighi, Sagar dighi and Rajmata dighi compare to other ponds though the Dominance (D') is 0.1318 in Sagar dighi indicating most favorable among the studied ponds. Both Sagar dighi and Dangraidighi showing highest diversity indices in 'Shannon index (H)' and 'Simpson (1-D)' index compare to Policeline dighi showing the lowest. According to size Sagar dighi, Dangarai dighi, Lal dighi and Bairagi dighi are comparatively bigger in size and Policeline dighi, Lamba dighi are small. Calculation of number of species and number of individuals in log series, Fisher (alpha) is more than 1 (one) in all the studied ponds indicating comparatively good abundance record, except Policeline dighi which recorded the value 0.9218 . Photographs of some of the recorded zooplanktons are presented in Plate 2.

Table 2: Diversity Indices of the recorded Zooplanktons from different Pond of Coochbehar Town (Courtesy: Past software [Hammer et al., 2001]) [20]

\begin{tabular}{|c|c|c|c|c|c|c|c|c|}
\hline & Bairagi dighi & Lamba dighi & Rajmata dighi & Lal dighi & Dagarai dighi & Narasingha dighi & Sagar dighi & Poloceline dighi \\
\hline Taxa_S & 15 & 10 & 13 & 11 & 15 & 12 & 12 & 7 \\
\hline Individuals & 5030 & 7860 & 5050 & 6370 & 5180 & 3540 & 1950 & 1830 \\
\hline Dominance_D & 0.2332 & 0.2341 & 0.1705 & 0.1997 & 0.1404 & 0.2614 & 0.1318 & 0.5399 \\
\hline Shannon_H & 1.898 & 1.722 & 2.034 & 1.855 & 2.222 & 1.672 & 2.205 & 1.027 \\
\hline Simpson_1-D & 0.7668 & 0.7659 & 0.8295 & 0.8003 & 0.8596 & 0.7386 & 0.8682 & 0.4601 \\
\hline Evenness_e^H/S & 0.4446 & 0.5595 & 0.5882 & 0.5812 & 0.6149 & 0.4438 & 0.7562 & 0.399 \\
\hline Menhinick & 0.2115 & 0.1128 & 0.1829 & 0.1378 & 0.2084 & 0.2017 & 0.2717 & 0.1636 \\
\hline Margalef & 1.643 & 1.003 & 1.407 & 1.142 & 1.637 & 1.346 & 1.452 & 0.7987 \\
\hline Equitability_J & 0.7007 & 0.7478 & 0.7931 & 0.7737 & 0.8204 & 0.673 & 0.8876 & 0.5279 \\
\hline Fisher_alpha & 1.904 & 1.13 & 1.615 & 1.294 & 1.895 & 1.552 & 1.704 & 0.9218 \\
\hline Berger-Parker & 0.3936 & 0.3511 & 0.3089 & 0.2826 & 0.2722 & 0.4068 & 0.2154 & 0.7213 \\
\hline
\end{tabular}

Very high counting of Cyclops in Lamba dighi, Lal dighi indicating high level of organic pollution (Pal et al. 2015) needs further investigation of limnological parameters to know the actual cause of their dominance.

Plate 2: Photographs of plankton recorded from different ponds of Coochbehar town.

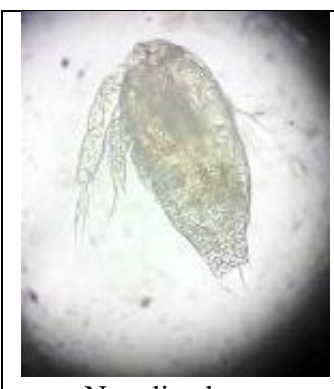

Nauplius larva

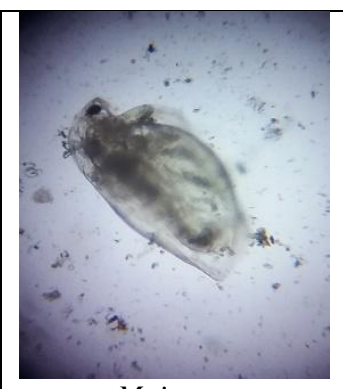

Moina sp

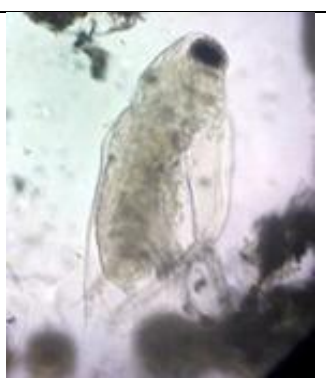

Diaphanosoma $s p$

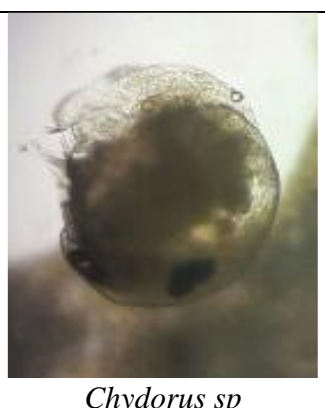

Chydorus $s p$ 


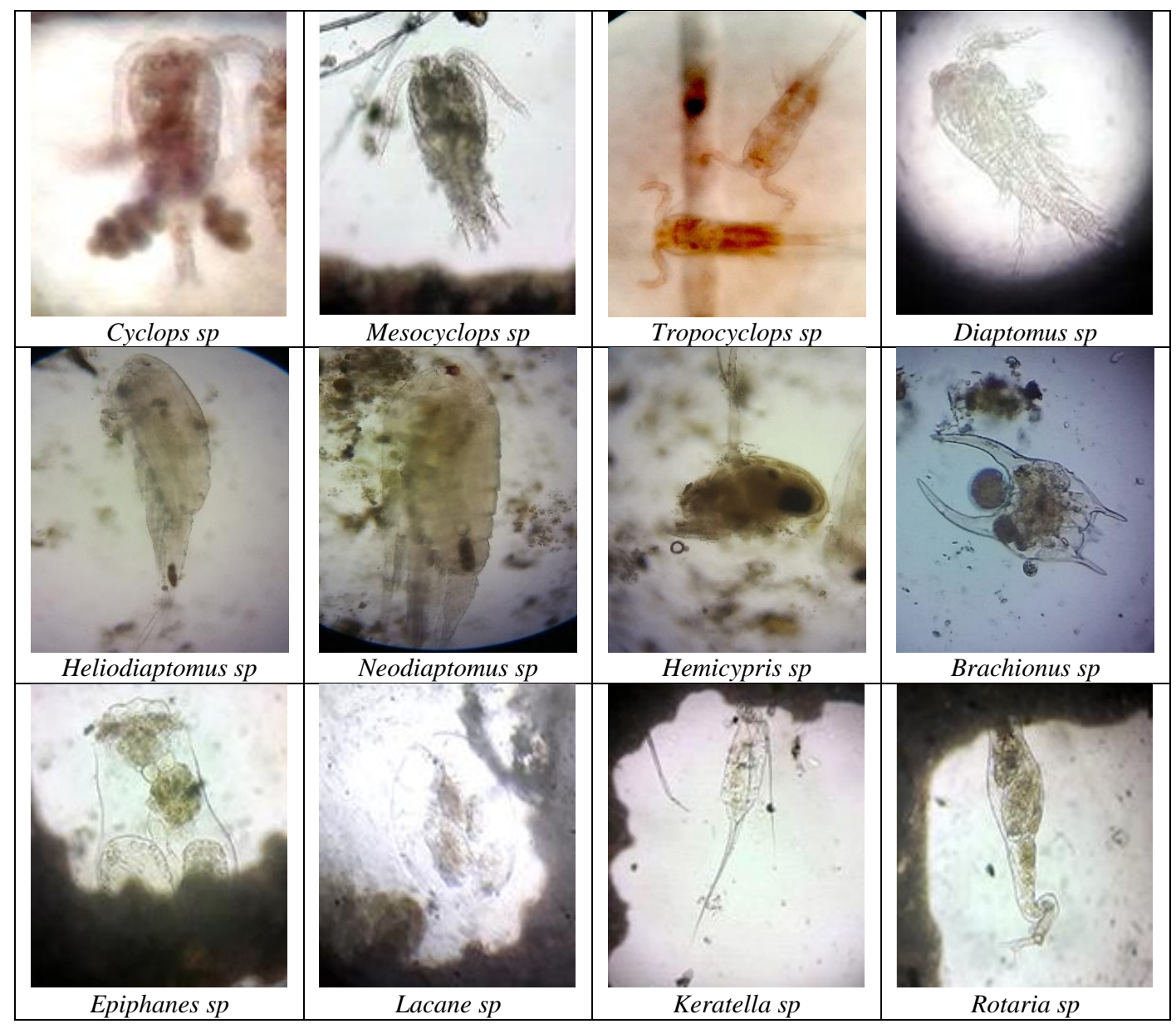

\section{Acknowledgement}

The authors are thankful to the authorities of Tufanganj Mahavidyalaya and Cooch Behar Panchanan Barma University for giving permission to carry out this work.

\section{Reference}

1. Datta T. Zooplankton Diversity and Physico-Chemical Conditions of Two Wetlands of Jalpaiguri District, India. International Journal of Applied Biology and Pharmaceutical Technology. 2011; 2(3):576-583.

2. Harris, JM, Vinobaba P. Impact of Water Quality on Species Composition and Seasonal Fluctuation of Planktons of Batticaloa lagoon, Sri Lanka. Journal of Ecosystem and Ecography. 2012; 2(4):1-6.

3. Pal S, Das D, Chakraborty K. A comparative study on physico-chemical characteristics and Zooplankton diversity between natural and man-made wetlands at Cooch Behar, West Bengal, India. Ero. J Exp. Biol. 2015a: 5(5):85-97.

4. Ahmad U, Parveen S, Khan AA, Kabir HA, Mola, HRA, Ganai AH. Zooplankton population in relation to physico-chemical factors of a sewage fed pond of Aligarh (UP), India. Frontiers in Life Sciences: Basic and Applied: Biology and Medicine. 2011; 3(2):336341.

5. Das D, Sen A, Mitra P. Major Fauna of Rasik Beel (West Bengal). OP Edi. The Director, Zoological Survey of India. Kolkata. India. 2013; 343:1-76.

6. Mondal, Pal D, Ghosh J, Biswas TK, Rotifer AK. diversity of Mirik Lake in Darjeeling Himalaya, EJEB. 2012; 2(5):1451-1456.

7. Mondal D, Pal J, Ghosh TK, Biswas AK. Diversity of Cladocerans and Copepods of Mirik Lake in Darjeeling
Himalaya. JTBSRR. 2013; 2(1):36-46.

8. Patra AK, Das V, Datta T, Ghosh SD. Zooplankton fauna of Moraghat forest, a territorial forest of Jalpaiguri district, West Bengal, India. EJEB. 2015; 5(1):39-47.

9. Das D, Sen A, Mitra P. Biodiversity of Rasik Beel Wetland Complex (WB, India). In Proceedings of International Wetland Symposium (IWS) 2012. Pub. by Conservation and Sustainable use of Wetlands in Nepal (CSUWN), Nepal, 2012.

10. Pal S, Das D, Chakraborty K. Studies on the Physicochemical characteristics and Zooplankton diversity of the 'Panishala Beel': A wetland in Cooch Behar district, West Bengal, India. In Modern Trends in Social \& Basic Sciences. Ed. S. Debnath, B. Bagchi \& S. Mishra. Pub. Readers Service. Kolkata, WB. India. 2015b:143-157.

11. Sehgal KL. Planktonic copepods of freshwater ecosystems. Interprint, New Delhi, 1983.

12. Battish SK. Freshwater Zooplankton of India. Oxford and IBH Publishing Co, New Delhi, 1992.

13. Sharma BK. Freshwater Rotifers (Rotifera: Eurotatoria) Zoological Survey of India. State WB. 1999; 11:341468.

14. Venkataraman K. The Freshwater Cladocera (Crustacea: Brachiopoda) Zoological Survey of India. State Fauna Series 3, Fauna of West Bengal. 1999; 10:251-284.

15. Shannon CE, Weaver W. The mathematical theory of communication. Urban. University of Illinois Press, Urbana, USA, 1949.

16. Margalef R. Diversidad de especies en las comunidales naturales. Publicaciones del Instituto de Biologla 
aplicada. Barcelona. 1951; 9:5-27.

17. Menhinick EP. A Comparison of some species Individuals diversity indices applied to samples of field insects. Ecology. 1964; 45:859-881.

18. Pielou EC. The measurement of diversity in different types of biological collections. J of Theoretical Biology. 1966; 13:131-144.

19. Sheldon AL. Equitability indices: dependence on the species count. Ecology. 1969; 50:466-467.

20. Hammer $\varnothing$, Harper DAT, Ryan PD. PAST: Paleontological Statistics Software Package for Education and Data Analysis. Palaeontologia Electronica. 2001; 4(1):9. 